\title{
"To you, to us, to oil and gas" - The symbolic and socio-economic attachment of the workforce to oil, gas and its spaces of extraction in the Yamal-Nenets and Khanty-Mansi Autonomous Districts in Russia
}

\section{GERTRUDE SAXINGER}

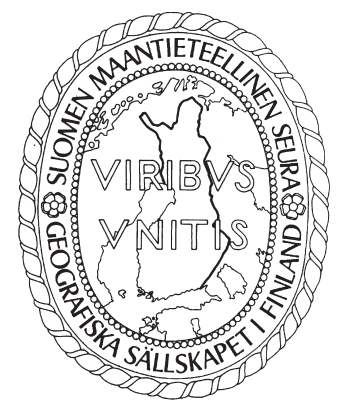

\begin{abstract}
Saxinger, Gertrude (2015). "To you, to us, to oil and gas" - The symbolic and socio-economic attachment of the workforce to oil, gas and its spaces of extraction in the Yamal-Nenets and Khanty-Mansi Autonomous Districts in Russia. Fennia 193: 1, pp. 83-98. ISSN 1798-5617.

This article examines ways in which workers and the people around them become enmeshed with oil and gas resources, the extractive industry and the social and geographical space of the Russian Far North: in particular, the YamalNenets and the Khanty-Mansi Autonomous Districts (YNAO and KMAO). It highlights how both the local workforce and the long-distance commuters who travel back and forth from all over Russia develop strong attachments to the social and economic meaning and symbolism of oil and gas. New labour conditions and a new configuration of the labour market have emerged in the context of privatization and out-sourcing in the last two decades. These changes have created new certainties and uncertainties for the future in a region that until now has been conceived as harsh, but stable, and as conferring both prosperity and privilege on those who can cope with the extreme conditions. This study is based on ethnographic long-term fieldwork in YNAO and KMAO.
\end{abstract}

Keywords: extractive industry, mobility, long-distance commute work (FIFO), place attachment, actor-network theory, Circumpolar North

Gertrude Saxinger, Department for Social and Cultural Anthropology, University of Vienna, Austrian Polar Research Institute (APRI), Universitaetsstrasse 7/C412, A-1010 Vienna, Austria,E-mail: Gertrude.Eilmsteiner-Saxinger@univie.ac.at

\section{Introduction}

It is rare to find occasions when vodka is drunk without an accompanying toast "to oil and gas". This toast is heard throughout those regions of northern Russia with links to the petroleum industry. People live directly or indirectly with oil and gas as workers, engineers, managers or CEOs and as the inhabitants of mono-industrial towns in the Russian North - such as the Yamal-Nenets and the Khanty-Mansi Autonomous Districts (YNAO and KMAO) - or as long-distance commute (LDC) workers coming to the North ${ }^{1}$ from all over Russia. "Oil is feeding us and Russia", they say, and the advertisements of companies and city administrations show how gas makes "lives sunnier and brighter". The geographic location of the resources and the adjacent industry towns in the tundra or taiga of western Siberia means working and living under severe climatic conditions and in remote areas. To compensate for this, workers typically receive higher salaries, along with supplementary payments according to a legally defined "northern coefficient" (Kozlinskaya 2009). This prospering sector demands a highly qualified workforce. The large companies in the mono-industrial cities, many of them the direct or indirect successors to former state enterprises and most still fully or partly state owned, provide their employees with satisfactory working conditions, extra social benefits, and (compared to sub-contracting companies) sustainable employment. Furthermore, through corporate social responsibility programs, these companies are active in the towns' social and cultural life. Subsequently, the inhabitants have a high level of loyalty and commitment to "our oil and gas companies" which have come to symbolise the cities and their prosperity. 
At the same time, employment in the petroleum industry is becoming increasingly unpredictable due to the rise in the number of short-term contracts in the North, particularly in the construction sector. - This is a significant development compared to the Soviet period up until the early 2000s. A further degradation in employment conditions stems from the increase in outsourced work from major to sub-contracting and sub-sub-contracting companies, leading to decreasing social benefits, lower salaries and, longer shift-rosters. These conditions particularly impact young, low qualified workers who are about to start their careers, resulting in lower social mobility, financial dependence on parents, and in many cases the necessity of actually living at their parents' place with their own young family. Nevertheless, they are fortunate in being employed; a much more favourable situation compared to other remote regions of central Russia, where socio-economic development still lags behind even two and a half decades after the dissolution of the Soviet Union.

Despite these changes, the rich hydrocarbon resources of north-western Siberia, which are the focus of this article, are still symbolically and socio-economically meaningful to the labourers, the industry and the state.

The purpose of this paper is to investigate the ways people relate to oil and gas and the spaces of extraction. The following questions will be addressed: in which ways do long-distance commuting petroleum workers from central Russian regions and those who are residents in the YNAO and KMAO build up symbolic and socio-economic relationships to oil and gas? What are the factors that cause people from central Russian regions to work as long-distance commuters or to stay as permanent workers living in the North?

These questions are analysed through the theoretical prism of actor-network-theory (Law 1992; Latour 1993), and Ingold's (2011) theory of meshworks of people and their material environment as well as experiences. Furthermore, an examination of the perception of the materiality of resources and their symbolic meanings on the ground must also look at entanglements with the political economy (Nash 1979; Wolf 1982; Ferguson 2005, 2006) and broader socio-economic and political processes (Burawoy 1998). The interpretation of spatial relations to the resource rich North is inspired by the works of Löw $(2001,2008)$ and the geographers Massey (2005) and Cresswell (2004) in terms of understanding how people experience this northern space - exemplified by YNAO and $\mathrm{KMAO}$ in this article - as both 'extreme' and 'normal' at the same time (Eilmsteiner-Saxinger 2013a, 2013b).

This paper is based on my anthropological-geographical research - eleven months in total, beginning in 2007 - in several mono-industrial towns of YNAO and KMAO, with a special focus on the city of Novy Urengoy in YNAO as well as on small and large shift-workers' camps in this region. Furthermore, I visited workers and their families in the central Russian Republics of Bashkortostan, Chuvashia and Tatarstan. The findings also result from my mobile fieldwork on long-distance commuter trains between Moscow and Novy Urengoy, on which I travelled several times back and forth $(25,000$ kilometres in total; one way is three and a half days on the train). This allowed not only indepth participant observation but also a wide range of informal talks with oil and gas workers about their life, their work and the meaning of oil and gas to them.

\section{The attraction of oil and gas}

If I turn on the gas stove in my Viennese kitchen, I am directly connected to my fieldwork region. It takes a week for natural gas to travel from Novy Urengoy which its inhabitants affectionately call the "Russian gas capital" - through the so-called "friendship pipeline" that travels via the Ukraine to the Baumgarten gas distribution hub, to the east of Vienna/Austria (Zirm 2007). In particular the Urengoy gas field at the Arctic Circle is the Russian source of the natural gas supply for Europe.

Industry, the Russian state, and the people working in the petroleum industry are embedded in the symbolic, social and socio-economic conditions of the North as a physical and social space. Both the buyers and sellers of oil and gas are tightly connected with these rich resource spaces: for instance, the EU Commission estimates that $60 \%$ of all gas imports come from Russia up until 2013 (Euractiv 2010). In 2009, $36 \%$ of the European Union's natural gas imports, as well as $31 \%$ of its crude oil imports, came from Russia (Directorate-General for Energy and Market Observatory for Energy 2011; Eurostat 2011). Between 2000 and 2008, imports of crude oil from Russia to the EU rose by 59\% (Eurostat 2011). Russia is in turn dependent on steady markets like those in the EU, as well as on stable crude oil prices. $70 \%$ of Russian natural gas exports and $80 \%$ of crude oil exports go to 
the European Union (EU Commission 2011). Despite political discussion in Russia about the need for urgent modernization and re-orientation towards new technologies and the development of other branches of industry and the economy, natural resources and the energy sector remain the main drivers of the Russian economy, and the main source of income in the national budget. In 2011, 52\% of the income from all exports came from oil and an additional $12 \%$ from gas. The fiscal revenue from oil and gas rose between 2001 and 2011 from $20 \%$ to $49 \%$ of the entire national revenue of Russia (Gustafson 2012: 4-5; cf. Moe \& Wilson Rowe 2009; Moe \& Kryukov 2010). Oil and gas are also amongst the most socially meaningful natural resources and subjects to wide global fluctuation related to price, availability, extraction and processing technologies, as well as geo-political interests. Due to the wide range of usages of fossil fuels, oil and gas rank among the most precious materials that humans use. The North, so rich in natural resources, and the petroleum industry built around had allowed the Russian state to avoid necessary economic reforms relating to economic diversification. The existing deposits in Russia will remain a geopolitically relevant player in the long term (cf. Stern 2005; Gustafson 2012).

The development areas of oil and gas in Russia continuously shift towards the North, beyond the Arctic Circle and into the peripheries of Siberia (Saposhnikov \& Chudnovskiy 1988; Gerasimchuk 2012). Due to the increasing distance of the extraction sites from urban areas and from the densely populated European part of the country, long-distance commuting has become an increasingly popular response. The people making a living migrate along with the moving oil and gas development areas and companies. The life cycle of many extraction sites has already come to an end, but as they diminish, new ones open elsewhere. However, the petroleum industry is not only spatially, but also temporally dynamic. The extraction of oil and gas is either reduced or boosted depending on their fluctuating prices. Workers are considered as depersonalized "human resources", and like the fossil resources they are also subject to the laws of pricing according to accessibility and availability. A boom period makes the industry more dependent on qualified professionals while a period of bust reverses this dependency. Beyond that, a decline makes the development of new deposits and thus of new employment more difficult, because investments in exploration and development are tending to decrease (cf. Moe \& Kryukov 2010). Depending on the geographical position, the geological con- ditions, the available technology and infrastructure, prospected fields are sooner or later transferred into the exploitation process. This also depends on the nature of the workforce currently available. These macro-economic and institutional conditions signal to the workers that they are directly bound up with the dynamics constituting the value of this natural resource, i.e. the oil and gas prices. Furthermore, the phenomenon of the mobile workforce forms a part of state discussions about demographic issues. These discussions turn on whether northern towns should increase in order to meet the demand for workforce, or if they should consequently shrink through resettlement of pensioners and the unemployed while increasing the number of long-distance commuters (Hill \& Gaddy 2003; Heleniak 2008, 2009; Nuykina 2011).

Long-distance commuters as well as local oil and gas workers are as closely connected to oil and gas and their socio-economic value, as are the industry and the state. These natural resources are emotionally and symbolically a part of everyday social life, not only for workers in the industry but for the entire region. The widely used drinking toast - "to you, to us, to oil and gas" - reveals the strong emotional connection to these natural resources "for Russia" (Fig. 1), that "feed Russia" and
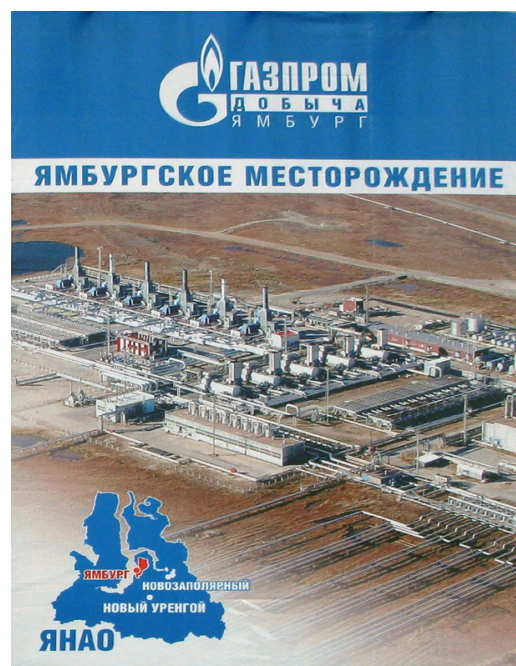

Fig. 1. Advertis em ent: "The energy from natural resources for Russia".
ЗНЕРГИЮ НЕДР POGQKL! w w w . y a mburg . ru 
that "are serving the people" (Fig. 2); this is shown excessively in the advertisements in towns and along the roads in the tundra and taiga.

The immediate social and emotional connection of the industry to oil and gas goes also beyond the economic dimension, and can be best understood through the prism of its advertisement and PR strategies. The advertisement images establish an emotional connection to the area and the ground. The motifs have remained almost the same for decades and across generations. The ideologically charged video of the Gazprom company hymn very powerfully illustrates this: the "sun beneath the earth [...] stores the energy for the nation" and "heats our offices and houses". It "warms us from within the earth". The chorus calls people to toast "to you, to us, and the all-Russian gas" (Tumayev 2009). These motifs have been selected because they evoke particular positive feelings and people identify with them so readily. This is not only true for those who live in the northern mono-industrial towns, but also for those who commute there from a long-distance. People reiterate these images that date back over decades: many old songs abound about the resource, the hard work necessary to extract it and the experiences of life and work in the extreme cold.
Gas workers, oil workers and engineers are proud of their professions and their efforts in extracting the wealth for the nation, and of course for themselves. Festivities for the various professions with patriotic ideologically laden speeches are regular events in the course of the year. The gas flares emitting from the refineries, visible from afar, are symbols of the on-going production day and night. The sight makes people feel confident that all is right with the world. Several times, people pointed out to me these flare stacks as the symbols of which they are fiercely proud.

My focal impression is that the experience of the physical aspect of oil and gas not only exists as an economically relevant material, but as an emotionally evocative one that causes people to feel enmeshed with (Ingold 2011) based on its value, and by which they establish an emotional, lived relationship. Thus, the natural resource - oil, gas, gas condensate - becomes an actant, because it forms a network with people, spaces and institutions (Law 1992; Latour 1993).

The ascription of meaning to experienced spaces takes place within an amalgam of local and national practices, of agents and the global political economy. People travel half of a week to Novy Urengoy and gas travels one week to the European gas distribution hub Baumgarten in Europe (Zirm

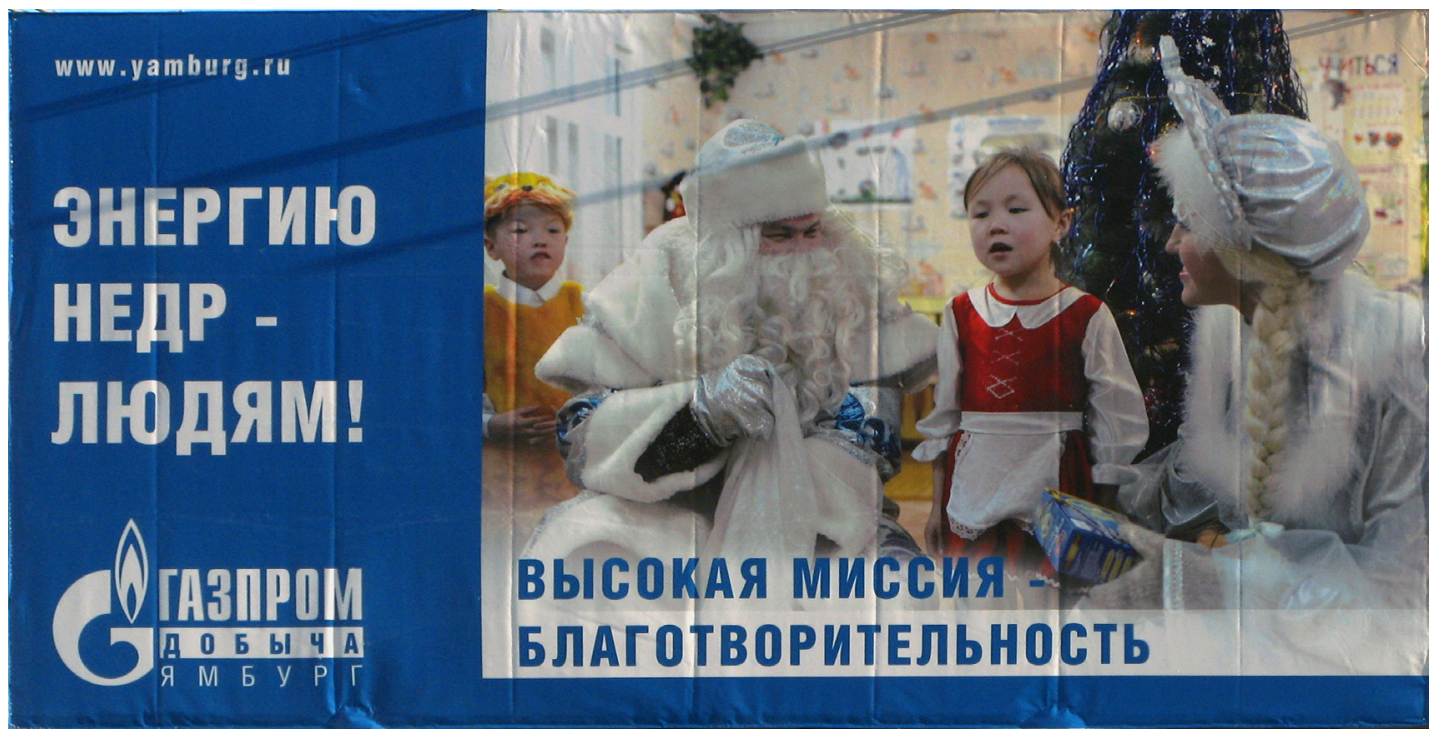

Fig. 2. Advertisement: "The energy from natural resources for the people. The great mission: welfare". 
2007): fossil resources to the south-west, human resources to the north-east. Both categories - material and social - are on the move. They are interwoven mainly by people who become dynamic objects as human resources, such as the long-distance commuters. Thus the fossil-fuel resources are, for those who earn their living and draw yields from them, highly significant in a social sense. They are no less significant and socially constructed for the Russian state. For both the sellers and the buyers, they are of geo-political interest. They are significant - consciously or unconsciously also for the users of oil and gas to a certain extent.

Like other natural resources, oil and gas, along with the areas in which they are extracted, not only have a material dimension but also a significant social, economic and symbolic dimension. These dimensions relate to dynamic pricing as well as to the limited amount of these natural resources. This finite nature produces an immediate dependency on its availability, and a global competition for it. This is accompanied by the above mentioned fluctuating economic value for the energy carriers and the meaning of its supply for the local community immediately affected by it, as well as for global society. Oil and gas and their production sites are dynamic, and so the people delivering these natural resources are mobile and socially organized in a dynamic way.

As has been said, there is a social, economic and symbolic entanglement of oil and gas, the North, and the long-distance commuters in Russia. There is therefore a tight connection between the workers' emotions and experiences and the materiality of oil and gas and their space of extraction.

\section{Attracted by the North}

This section discusses northern residents who are either working locally or who are intra-regional long-distance commuters to the extraction sites in greater distance to the northern cities. Since the 1970s people from the broad swaths of the Soviet Union were recruited in order to cover the workforce demands of both the fossil-fuel deposits to be developed and the construction of mono-industrial cities in north-west Siberia - a planning paradigm that was dominant up to the beginning of the 1980s. Although indigenous inhabitants of the North are working today in the petroleum industry (Dudeck 2010; Rouillard 2013), they were not explicitly considered as a part of the workforce when the ex- ploitation of natural resources in the western Siberian basin began. The reason underlying was that they were regarded as physiologically and culturally unsuited to jobs in this sector ${ }^{2}$.

The huge deposits in north-western Siberia, which had already been explored in the 1930s, were only continuously developed from the 1960 s onward. In the course of this development, the mono-industrial cities were built to house workers. Although it was considered, the Soviet regime did not decide on the system of long-distance commuting (Eilmsteiner-Saxinger \& Aleshkevich 2008; Aleshkevich 2010) as it was already implemented in, for example, the arctic Canada and in Alaska, but instead elected for the erection of permanent settlements and large cities. The long-distance commute workforce lives and work at the extraction sites far from home for shifts ranging from two weeks to two months, alternating with an equivalent rest periods at home. This is the predominant mode of labour organisation in remote areas today. Soviet bureaucrats contended that mobile people might more easily evade state control than sedentary ones (cf. Fillipov 1982), and furthermore, the sedentary paradigm should be seen in the context of a state-run process of domestic colonization, as well as within the paradigm of the submission of nature by technology for the industrial and social development of the socialist state.

In the latter half of the 20th century, the Soviet Union entered into a second phase of urbanization and industrialization of the northern peripheries. In this phase, a high economic price was paid for the construction of a complete social, cultural and technical infrastructure for these mono-industrial cities. The living costs per inhabitant of the cities in the permafrost areas of taiga and tundra are estimated to be three to four times higher (Hill \& Gaddy 2003: 125; Martynov \& Moskalenko 2008; Andreyev et al. 2009: 104) than in comparable cities of the densely populated central regions. This fact was already prompting criticism by the economists at the beginning of the 1980s when the significance of long-distance commuting was first discussed (Bogudinova 1981). Only in the 1980s did the Soviet Union, like other circumpolar countries before it, turn towards the system of long-distance commuting (Pashin 2004; Eilmsteiner-Saxinger \& Aleshkevich 2008; Aleshkevich 2010). Although the local workforce is still being recruited from the mono-industrial cities of the North, today 
long-distance commuting from all over Russia is an established system for delivering workers to the Russian natural resources industries.

The second industrialization period of the North did not claim as many human lives as the Stalinist industrialization by forced labourers in the Gulag system (cf. Stettner 1996; Stark 2003). The mobile lifestyle is not a new experience for many of the northern workers. Mobility and migration became a part of the identity of families due to their earlier voluntary or forced resettlement. In particular, my interlocutors from the Caucasus Republics, who were recruited as a qualified workforce from the traditional petroleum regions to work in the industry of the North, recount the waves of migration in the course of the last two or three generations. People from Chechnya in particular can recount another history of collective mobility besides the deportations that occurred towards the end of World War II, and their resettlement in the 1950s; the massexodus in the turmoil of the first and second Chechen War in the 1990s and 2000s.

Today the North, consisting of resident workers and those who long-distance commute in and out, is a melting pot of numerous nationalities, ethnic groups and languages. Besides the indigenous population of the North, there are inhabitants who have migrated from all parts of the former Soviet Union and Russia. Some of them stay for a few years, others until their pension or their death. As is often said, both long-distance commuting and the North of Russia are perceived by the workers and their families as both extreme and normal at the same time (Eilmsteiner-Saxinger 2013a, 2013b). An important caveat, however, is that the extreme in this sense not only connotes something arduous or negative, but also something positive.

The extremity of this place is a source of identity that is defined by participating in something special; for the long-distance commuters as for the northern residents. For those who came under the ideological conditions of the development of the North, it was a participation in a project of civilization (tsivilizatsiya) and of exploitation (osvoenie) for the prosperity of the motherland (rodina) and the socialist nation. For many it was also romanticism and adventure that drew them to the North, and, besides the opportunities to make money, these are still the main reasons why people may decide on a life as long-distance commuters going back and forth between the southern regions and the North, in particular to YNAO and KMAO.
"I came here for romantic reasons, like so many of us. It was fascinating. We were young and many of us weren't married yet. Young people met here and found a partner for life. We lived an adventurous life in an utterly unknown region we knew nothing about, and where there was nothing. Back home there were adverts everywhere which promised good jobs in the North. We were young and wanted to experience something and see the country." (Marina Filipovna) ${ }^{3}$

For many employees the migration or long-distance commuting to the North was often the only possibility to move within the Soviet state, or to move away from home.

The central significance of the North for people, state and industry lies in the ascription of attributes such as 'hostile' and "climatically harsh", which became clearer in my investigation. The North, with its unimaginable, fascinating but also dull vastness is not a normal, but rather an unfavourable living space that requires a large amount of effort to adjust to (adaptatsiya) and turn it into normality. These terms can be found today in the literature of many scientific fields about the North of Russia (cf. Rouillard 2013). At the same time, precisely these ascriptions are the positive moment of many identity constructions. Without the hardship of this extreme place, the identity-defining attribute of accomplishing something special, which is especially honoured by the family, cannot be achieved (Eilmsteiner-Saxinger 2013a, 2013b).

According to the view of the non-indigenous population, the North has to be made into a place for living and working through industrialization:

"When we got here there was practically nothing. I had no idea what this North was. Although I knew that it was going to be cold, the clothes I had brought were totally inadequate. We built a city and a civilization here under the most adventurous conditions." (Marina Filipovna)

Awareness among both the residents and the long-distance commuters that the North has been a living and working place for the indigenous population for millennia is not considered a relevant factor in the discourse of the development of the North as a civilized place (Stammler \& Wilson 2006; Stammler 2011). In this way, a clear boundary is drawn between the indigenous and the industry-related population. The perspective of imperial colonization imposes a severe limitation onto the traditional ways of life, e.g., that of the reindeer-herding nomads. On the other hand, the 
view that defends folklore is protectionist. The colonial view sees itself as bringing the civilization and this is understood as a legitimate reason to acquire natural resources for the good of the nation.

The workers thus perceive the North as a place which was built with their own hands under extreme conditions and with the spirit of 'pioneers'; again this is true for the older long-distance commuters as well. My research, and that of Bolotova and Stammler (2010) (cf. Stammler \& EilmsteinerSaxinger 2010), demonstrate this. This generation still calls themselves 'pioneers' (pioneri), and in many cities of the North street names such as the "street of enthusiasts" (ulitsa entuziastov) bear witness to this self-assessment. Medals like the one for the "hero of labor" (geroy truda), or awards within the "Stakhanov movement" signify individual prestige and measures taken by the state to enhance careers (Ljapin 1952). The history of this period is honoured in the museum of the Gazprom Dobycha Yamburg company (this operates with long-distance commuters only) in the camp of the Yamburg gas field with a permanent and thematically specific exhibition. The museum exhibits both the uniforms of the 'Stakhanov' groups and the medals and numerous photos of the "people who first moved there" (pervoprokhodtsy) ${ }^{4}$, those who travelled the 200 kilometres from Novy Urengoy to Yamburg in ten days with heavy-duty vehicles (today it takes four hours by car):

"The atmosphere was fantastic and the people in
the collective were close friends. This was neces-
sary for survival because we lived together in an
extremely confined space. It is different today. The
successive generations of workers came here when
everything was already built, and the young ones
can no longer imagine how we had to build every-
thing from scratch. Today Yamburg is an excellent
[commuter] city with all the most up-to-date fea-
tures. There is even a church." (Eduard Stepanovich)

But it was not only these ideological factors that led people to the Northern centres including YNAO and KMAO. A patriotic attitude was also necessary in order to be selected by the recruiting procedures (komsomolskaya putevka) of the youth organization of the Communist Party (the Komsomol) for employment in the North.

"Perhaps I am still a communist. (Laughs). But I was ready at all times. After my studies at the technical university I went to Mongolia, then I married and our first daughter was born. I remember when her mother stepped out of the helicopter with her still in the basket. We still lived in Nadym, the first city here at the Medvedze gas field. At first we were staying in the large tents, but when my family followed we were given a balka [a small wooden house] and when they were built we moved to the derevyaska [a two-storey wooden barracks with small flats and one common kitchen on each floor]. The city developed and life became more civilized. Our second daughter was born in 1986, when we were in the North. We already had a hospital. Everything was already normal. In the 1980s careers could be made in the North, and I wanted to work my way up. I went where the [communist] party sent me. [...] In 1986 I came to Chernobyl as a likvidator. Just as we did not know what to expect in the North, so we either did not know what to expect in Chernobyl. But there was no question that I would go for my motherland." (Vyacheslav Antonovich) ${ }^{3}$

With the inconvenience and difficulties of the sub-Arctic climate of the tundra and taiga, and of the construction of a feasible living environment, comes a feeling of legitimately gaining substantial privileges that are the social and financial reward for the hardships endured in the special and extreme conditions (ekstremalnye usloviya) of the North. These privileges were developed in the Soviet Union and include both the privileged access to general consumer goods, which were made accessible in the North, and the car for which one did not have to wait ten years, even though the streets only stretched a few kilometres in the island cities of the tundra, as I was humorously told in a conversation. Take on work in the North meant, both then and today, a guaranteed career. The state companies provided housing for their employees in the central regions as second homes with the intent to lure people back south after retirement. Earlier, there generally were - and in some companies still exist, although adapted to contemporary needs - special non-financial benefits (sotspaket), such as free access to holiday camps or sanatoriums at the Black Sea, as well as access to living space and goods that in the "economy of scarcity" were not normally available, or could only be gained via informal connections. There were also special shops at the first long-distance commuter camps, as my companion in Yamburg recounted during a walk through what is still the largest long-distance commuter camp in Russia (and the Soviet Union):

"The shops were packed here. We were able to buy perfume, radios, electronic goods, clothes and many other things. There were all sorts of sausage and cheese. It was of course expensive but we earned well. When shopping, we bought as much as we could carry home to the south. In the 1990s, 
when the economy went down and money was not worth much anymore, we also used these things to barter with. That was of course a problem at some point. Then, before boarding a flight back to the South your bags were inspected, because the luggage was much too heavy and it was absurd that all these things were transported to the North and then people flew it back again. That food was meant for living well here and not for feeding all the relatives back home." (Tamara Dmitrovna) ${ }^{3}$

Thus, there was primarily a personal socio-economic motivation for people moving to the North. The population living in the North still has the right to an additional pension as well as additional salary of up to $80 \%$ of the standard wage depending on the regional latitude. Similarly, the inter-regional long-distance commuters can claim a higher pension, calculated according to an equated coefficient that depends on the worker's number of earning years, and the additional salary as mentioned above. However, for them this counts only for the duration of the shift while they are actually located in the North (Kozlinskaya 2009).

As a result, the systems that make working life in the North appealing have remained pretty much the same since the time of the Soviet Union. As the findings of my research show, there are strong similarities between the reasons embedded in the current free market economy to work in the North (primarily but not exclusively economic factors) and those of the Soviet times. However, back then the reasons could not only be attributed to the ideological enthusiasm of the young Komsomol members, but also included the privileges and financial rewards to be expected, which were part of a general socialist work ideology whose aim was to boost productivity by competition between the workers (Ljapin 1952).

As mentioned above, for many the motivation for remaining in the North is the notion of belonging to the group of the so-called pioneers and being strongly rooted there. This first generation of immigrants has built its social networks in the North and raised its children there, who now also work for the companies of the city or as intra-regional long-distance commuters. Many of the second generation studied in the central region, lived in the apartments mentioned above which were built by the employing companies, and came back to the North in order to build a career and start a family. The social benefits available to the employees of companies close to the state include an annual free flight to the central region for them and their families, which enables interaction between the residents of the North and their second home in the central region.

The mono-industrial cities in the petroleum regions of the North today offer a consistently high quality of life for all generations with a well-functioning cultural and social infrastructure. Compared to those of the central regions the wages are high. They can be compared to the average wage of Moscow and Saint Petersburg. For well-trained people there is an employment market that is searching for highly qualified professionals. The high wages - compared with those in jobs in the public or service sector - are not only a result of the highly paid petroleum sector, but also of the extra wages and pensions mentioned above, earned in the course of a professional life in regions which are legally qualified as the "Far North" or "equivalent to the Far North". Although I met many people who left the North immediately after becoming pensioners, and who want to move back to their apartments or houses in the central regions, there is also a discourse which favours staying behind. It is not uncommon for those who have lived many years or decades in the North and who have adapted to the climate to die of a heart attack a few years after returning to the central region. At this point however, it is difficult to prove if early death - in this context it is mainly men - is connected to the return to the mild climate or to the general low life expectancy of Russian men, which is approximately 60 years. The connection with the return to the central region is not medically proven, but this fear nevertheless exists (cf. Rouillard 2013).

The employees located in the North benefit from the contracts negotiated between the enterprises and the regional government (EilmsteinerSaxinger 2011), which in cases of equal qualification provides for a preferential recruiting of the local population ${ }^{5}$. The cities of the North that are connected to the petroleum sector have a young demographic and almost total employment. Last but not least, the successful adjustment to the climate of the tundra and taiga is the main reason for wanting to permanently live in the North such as in YNAO and KMAO.

There are numerous mixed forms of mobile life of long-distance commuters and their families. Some start their careers in a Northern city and switch over to inter-regional long-distance commuting; alternatively, inter-regional longdistance commuters may settle in the cities of the 


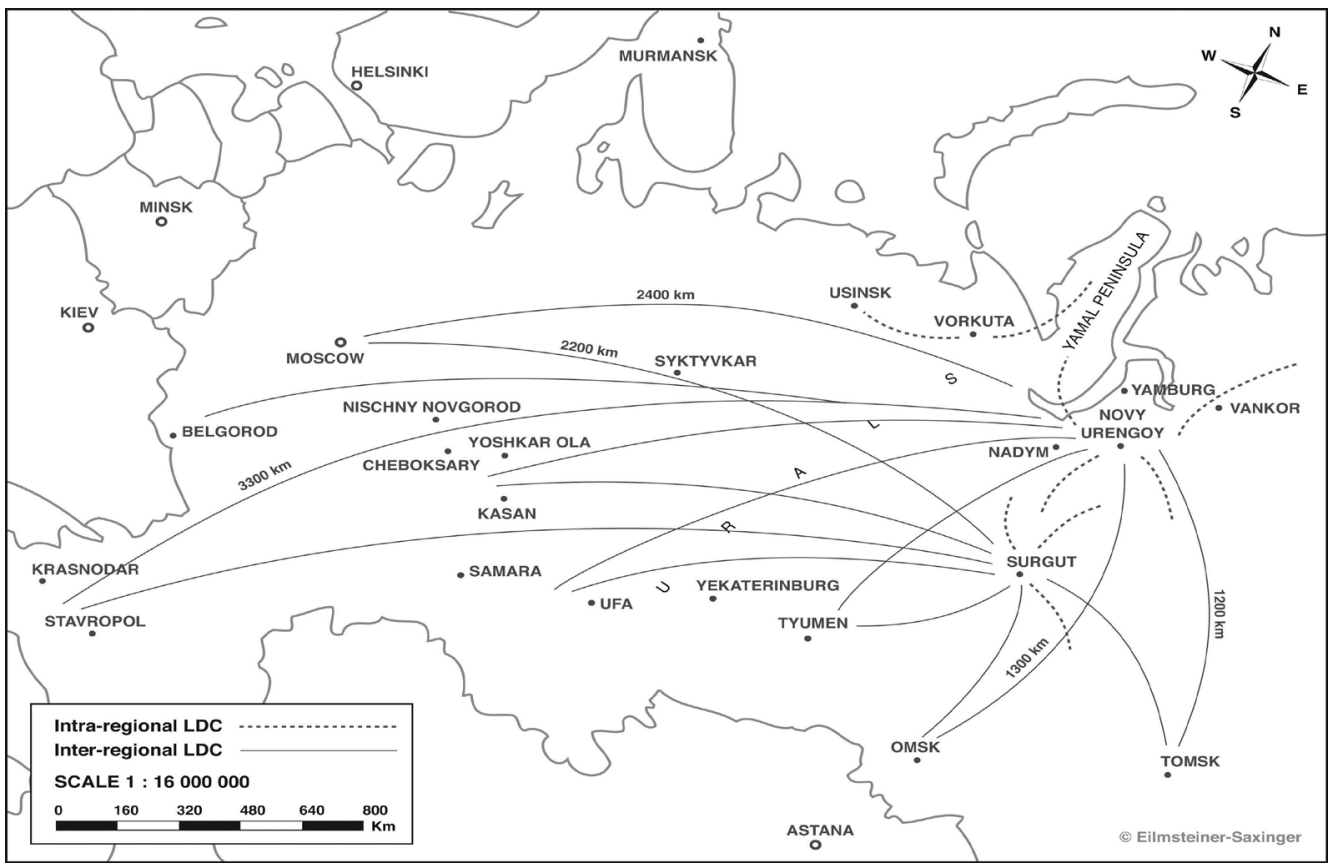

Fig. 3. Main travel routes of the long-distance commuters.

North and work locally, or commute long-distance intra-regionally.

\section{Commuting from the Central Regions and the enlarged mental map}

Inter-regional long-distance commuters mostly, although not exclusively, come from traditional petroleum regions. They come from places like the border city Belgorod, the hub leading into Ukraine, from Moscow, Samara, Yoshkar Ola, Cheboksari, Kazan, Omsk, Tomsk, Tobolsk, Kurgan, Perm and many others (Fig. 3). The socio-economic significance of this can be demonstrated by the example of the Volga region where, according to the viceprime minister Balabanov of the Bashkotorstan Republic, about 100,000 people (out of a population of four million) work as long-distance commuters (Regnum 2011).

As in most Russian regions outside of Moscow and Saint Petersburg, the Volga region, to which the Republic of Bashkortostan belongs, has still massive social and economic problems, such as low wages and a high unemployment rate, twenty years after the disintegration of the Soviet Union.
In the Volga region, the average monthly income is 21,788 rubles (€438), while in KMAO and in YNAO - the Russian centres of oil and gas production - the average monthly income is 50,575 rubles $(€ 1,016)$ and 67,194 rubles $(€ 1,350)$, respectively (Rosstat 2014). In this way, employment in the petroleum industry of the North has become an important factor in the local and regional economies of the long-distance commuters' regions of origin. Compared with the working population in the local labour market, the families of long-distance commuters have an above average household income.

This in turn has a positive effect on the local markets in areas with a weak economy. In Russia, the labour market in the natural resources areas of the North is of considerable significance for the population of the peripheries - i.e., regions outside of the prospering centres of Saint Petersburg or Moscow, and in particular for small cities and rural areas.

In addition, both the centres and the capitals of these regions benefit enormously from the incomes of the North through the increased consumption of this stronger economic group, as well as by the influx of people from the villages and small cities into the regional centres. In many cases, this influx is caused by the increased education available for 
children and better chances in the labour market for the non-long-distance commuting family members. Furthermore, travel from the regional centres to and from a work place in YNAO and KMAO is easier.

Let us take as an example one of Russia's, and indeed the world's, best paid jobs in this sector for blue-collar workers: the welders. This is a profession that is primarily performed by men and that often comes up in my research. It does not refer to automotive or domestic welding, but that performed in industrial complexes with tasks whose quality requirements demand practice and certification of several years. These workers are highly paid, for example up to 35,000 and 40,000 rubles (€800) per month in the central Russian Republic of Bashkortostan for the most highly qualified class. In YNAO and KMAO, they can earn up to triple the amount for this job. For those who fly to the Far East or to Sakhalin tickets cost up to $€ 800$, whereas train tickets to workplaces in north-west Siberia cost about $€ 80$ to $€ 100$. Tickets are partly paid by the companies, and partly not. Given these circumstances, inter-regional long-distance commuting is still profitable.

In the social group discussed here, cars and living space are mainly procured via loans and mortgages, with interest rates in the Republic of Bashkortostan being, for example, approximately $12 \%$ for accommodation and between $25 \%$ and $30 \%$ for consumer goods (UfaFinans.ru 2013a, 2013b, 2013c). Older employees carry the education costs for children, which have been rising for the last ten years, especially at universities and technical high schools. When a mother stays at home to look after her infant, her second income to support the young family is missing. It has become apparent that this is frequently the case:

"I am at home with the small children and cannot earn anything. I get 2,800 rubles from the state ${ }^{6}$. Furthermore, we are both on our second marriage, and for this reason my husband has to pay alimony for his child from the first marriage. This is not possible without the income [of the longdistance commuting partner]." (Olesya Vladimirovna $)^{3}$

There are fundamental financial reasons why people decide, at moments where the need for a higher income is the greatest, to take up work that requires long-distance commuting into the harsh climate of the resource peripheries. In the so called long-distance commuting dynasties, these decisions are made early and are determined on the one hand by education, which is already directed towards the petroleum industry, and on the other by the fact that long-distance commuting is a familiar form of working life for these families (Saxinger et al. 2014). Both the possible problems and the considerable advantages are well known to the children of long-distance commuting families and their communities. This makes their decision easier, as ethnographic data show. It may involve a deliberate refusal to take up long-distance commuting or encourage a conscious decision of pursuing a longterm mobile career in the petroleum industry.

Due to the comparably high wages and the well-known fact that the oil and gas industry is one of the most stable in Russia, increasing numbers of people are choosing to study at technical universities and take special courses in the numerous professions the petroleum industry has to offer. Two tendencies in regard to long-distance commuting can be discerned; parents with stable jobs help their children and relatives to acquire jobs in their companies, while others try to give their children an education which will not lead inexorably into the petroleum industry, so their children can have a life different to theirs. As Gennadiy Viktorovich, an older engineer, says, "my children study law and economics. In this way, life in the South is open to them". The extent of readiness for longdistance commuting is different in many families. Although in some families all or one or two members work in the North, other members of the family categorically refuse to do likewise, mainly because of health concerns, as a daughter in a longdistance commuting family told me.

Besides the economic connection of the North and the central regions, they are also socio-spatially integrated through long-distance commuting. In qualitative interviews, my correspondents recounted that they have close connections to the North through relatives and acquaintances who permanently moved there - for example to the north-west Siberian industrial cities like Surgut, Nishnevartovsk, Raduzhnyy, Kogalym, Nefteyugansk, Novy Urengoy, Gubkiskiy, Noyabrsk and many more. Inter-regional workers are not only connected through relatives and friends whom they visit while they are on duty in the North, but also establish a strong relation to the region, oil and gas that gives them work and causes them to live part-time in the North. Many told me that it became a second home, a place of individual freedom and an adventure, as well as a time-off from family responsibilities. 
Although the topos of the North as a metaphorical gold mine predominates, it is evident that this is not the only contributory factor driving longdistance commuting today. Two other things are important, just as they were in the Soviet period: the employees have to agree to the life-style in the long term and identify with a life of mobility lived multi-locally (Weichhart 2009). There are various motivations for choosing this mobile lifestyle. Today, as in the Soviet Union, the high salaries and other honorariums gained by long-distance commuting facilitate social progress. However, there is also a motivation of travel as such, a desire to see the country, an interest in the region of the North, and, for some, an adventurous spirit. As argued above, those who have been long-distance commuting for many years have put down roots in the North. This is a relevant coping strategy for integrating the sphere of home and the sphere of living in camps into a meaningful life as a whole. Many report that they can commune with nature while they are in the North; walk in the tundra and taiga, pick mushrooms and berries as a leisure activity. Others engage with the native population and buy fish and reindeer meat from them. And others might again have a lover or a second family in the North. Many variations of interaction with the northern space occur and cause the North to be incorporated as a meaningful part of life, to become a part of the long-distance commuters' mental map. The North integrates in this way with the central Russian and southern regions in an emotional, symbolic and of course in a socio-economic way and expands the mental map of people.

\section{The symbolism and meaning of the North and the petroleum industry}

The North of Russia - as well as Siberia - has been ascribed a number of formal and politically institutionalized as well as informal features during its history. This spans from the time of the Cossack colonization of czarist Russia - where it was also a matter of generating resources (e.g. the fur trade) - to the czarist ethnic-Russian settlements into areas with an indigenous population, including the period of colonization in the sense of the institutionalized conquest of the areas of Siberia and the Far East. This movement also included settlement by banishment and convict colonies, which continued within the framework of the Gu- lag network of the Stalinist period. The geopolitical and territorial solidification of the incorporation of the sub-Arctic, Siberian and far Eastern areas into the state occurred parallel with the exploitation of natural resources and the industrialization of these resource frontiers. There have been numerous political agendas behind the exploitation of natural resources in the North (osvoenie severa) that go hand in hand with concrete demographic strategies and settlement plans. These have originated from the period since the 1960s, when the petroleum industry rapidly expanded in the western Siberian lower basin and the western Siberian North, as well as from the 1980s onward when long-distance commuting became institutionalized. Thus the North has a deep social significance that comes from an era that long predates the period of the exploitation of natural fossil fuels or the history of czarist banishment and Stalinist deportations. In this history of the significance of the North, both the potential wealth and the extreme and threatening life conditions are inseparable from a colonial point of view.

For the employees in the petroleum industry, the North - in particular YNAO and KMAO - has the meaning of affluence and social mobility. The North attracts people and encourages them to put down roots there. As shown above, even the inter-regional long-distance commuters put down roots. An interlacing of the central regions and the regions of the North, rich in resources, takes place at the level of the employees in both a socio-economic and a more symbolic sociospatial sense. The practice of integrating the North into a part of one's personal life is not only significant for the individual who works in the petroleum industry in such a climatically, geographically and symbolically extreme region, but also conveys to the worker's home region the realities of life as a long-distance commuter. This is of central significance in explaining the readiness of people from the central regions to commute long-distance to the North. The North, which is commonly seen in Russia as an unknown region, becomes, via the long-distance commuters, a living reality for those central Russian communities who share this experience. The economically stagnating central regions grow together with the North, rich in the sense of the value of its natural resources, and the work places in the North become incorporated into the lives of individuals and society at large. Thus this 
integrated social space is characterized by its material and socio-economic conditions and by people positioning and institutionalizing themselves in relation to goods - in this case the valuable resources oil and gas. This is also true for state institutions and industry, which institutionalize the relational dependency on the northern natural resource areas.

Those who entered the petroleum industry only a few years ago - increasingly inter-regional long-distance commuters from the central regions - do not have a socialist Soviet memory of the petroleum industry. Hence, for them the North is still the place where good money can be made, while the older workers complain about degrading working conditions.

However, the reality and normality of the industry for those too young to remember the socialist era is current neoliberal practice, with its sub-contracting companies and privatizations. It is only when working conditions are against the law, and when a weak and inherently corrupt judiciary does not offer help, that modern business practice gains a new and extreme significance. As a result, it is not precise to speak of post-socialist conditions. Rather the term "re-socialist-neoliberal petroleum industry" would be more accurate. The term also indicates that in the sense of the vertical-power politics of President Vladimir Putin, re-socialist stands for re-nationalization tendencies and the state protection of resources and profits, whereas neoliberal stands for the conditions under which the employees, both stationary and long-distance commuters, are working today. As a consequence, employees as human resources are less significant in the eyes of the state than the natural resources.

\section{Conclusion}

This paper highlights the strong ties between people, the socio-economic potential of oil and gas and the extractive industry, which together form a network (Law 1992; Latour 1993) or define a meshwork in Ingold's (2011) sense. Oil and gas are associated with socio-economic well-being, stable work life and a life lived under extreme conditions. However, this symbolic and practical meaning is increasingly challenged by new conditions brought about by the industry and its continuous restructuring. Furthermore, the large companies that are running the mono-industrial towns are symbolically equated with the state through their Soviet legacy. In this sense, people are not only loyal to their companies but also to the state. This loyalty, however, is being eroded due to a diversified job market operating under neoliberal labour conditions, which especially disadvantages lower qualified people and increases job instability. Nevertheless, the general prosperity of the petroleum industry located in the remote North, such as in the resource rich districts YNAO and KMAO and their economic potential, still engender a strong attachment to these places and to oil and gas in general. People expect to earn a stable livelihood, be it as resident or as mobile workers. Therefore, the hydrocarbon industry of YNAO and KMAO still attracts people to move or long-distance commute there, especially from regions that were hit by the global economic crisis, which started in 2008.

The significance of the rich, but climatically, physically and psychologically challenging geographical zones has led me to focus on the theoretical conception of space in this paper. This focus is also a result of the numerous locations that characterize the life of the long-distance commuters: the home and the camps on site. Mobility does not only take place between geographically and temporally distant physical places. It occurs in places with specific material, ideal, economic and socio-temporal characteristics, which are constituted by relations between living beings and goods (cf. Law 1992; Latour 1993; Löw 2001, 2008; Massey 2005). This relational setting constitutes the human world and at the same time takes place within it - a world where social agency and social structures are of equal relevance. This aspect is significant when thinking about the integration of the regions of the North that are rich in natural resources with the structurally weak central regions that the long-distance commuters come from, both on a micro-level and on a macro-state level, which are then in turn embedded within a global structure.

How are people enmeshed with the natural resources, the extractive industry and this social and geographical space? A key sign of this relationship is the advertising of companies and the city administrations that shape the identity of the strong and reliable gas workers (gazoviki) and oil workers (neftyaniki). People directly correspond with these advertisements and messages, insisting to me that "what we do is important for us, for the industry and for the state". It part-constitutes their identity. Furthermore, the 'extreme' aspect of a 
society dwelling in the North and exploiting its valuable resource-commodities shapes workers' attachment to the place and creates a specific spatial atmosphere (Löw 2001, 2008). Identification with this place keeps alive the idea that people are a part of a worthwhile endeavour under extreme conditions. This extreme constitutes also a masculine identity that involves the individual's confidence of being capable feeding the family (in a patriarchal sense). They move back and forth according to their ideas regarding a successful life and they do it for their families. This life in the extreme has become normal for the people who devote themselves to it long-term (EilmsteinerSaxinger 2013a, 2013b).

The relation to oil and gas in the sense of a meshwork (Ingold 2011) or network (Law 1992; Latour 1993) is shaped by the significance of this material for economic prosperity and social mobility. The materiality of oil and gas must be looked at from the perspective of its social life (Appadurai 1988) as a commodity, meaning that the value of natural resources is dynamic. It is dependent on world market prices and delivery contracts made in the context of geo-political relations. The prosperity and stability of the industry depends on these factors and subsequently the people's stable employment. Once prices fall, investment into new fields and therefore into new jobs is scrapped. Furthermore, economic crises such as that of 2008 are often just an excuse to reduce salaries, and workers complain vociferously about this fact. On the other hand, the discovery and prospecting of new fields, as is presently the case, parallelly fosters also a spirit of optimism and a high level of trust in the industry and the state. An awareness of the limited nature of resources is not evident in everyday and political discourse. Oil and gas are essential material and symbolic parts of lives of the long-distance commuters and the residents in the resource rich regions of YNAO and KMAO. They say that these materials are "feeding them" and therefore foster social and economic prosperity for individuals and their families.

Among people from the southern and central regions of Russia, a feeling of "blue and black gold-rush" is apparent. The North is promising in both socio-economic and subsequently in symbolic terms; to put it in Cresswell's (2004) terms, the North is constructed as a meaningful place - in this case constructed by the people, the state and the industry. Especially in remote regions such as villages and small towns in central and southern
Russia, the economy is lagging behind, jobs and especially well-paid jobs are rare, making people desperate to go to the climatically harsh North. Many of them have never been there before. On the other hand, long-distance commuter networks have been established over time and established workers act as gate-keepers for jobs in the North. The economic motivation is at the forefront and along with that resources like oil and gas become symbolically meaningful. Working in the remote North also allows people to experience freedom, adventure and in many cases a life with a second partner besides the official spouse; these support putting down the roots. Therefore, they have incorporated the North into their social space that no longer consists of the home region in the south alone.

People from the northern mono-industrial cities who came there as pioneers (as did the inter-regional long-distance commuting pioneers) expect the continuity of a secure job that is well paid and contains special social benefits. Today however, the restructuring of the industry is bringing about unpredictability concerning sustainable jobs, and salaries are no longer as generous as they once were. People feel betrayed after what they have done for their motherland over recent decades, and the patriotism that was once strong is diminishing. In particular, low qualified workers or those who do not want to enter the extractive industry, of whom many are women, struggle with very low salaries, particularly in the service sector and in the state bureaucracy.

Today it seems that the state is trying to regain control over natural resources and state-shares in corporations are increasing. While state control over the resources is prevailing, strong efforts to protect labour conditions and the well-being of workers and citizens in the North does not seem to be on the state's political agenda. This is what I call a "re-socialist-neoliberal petroleum industry" (Eilmsteiner-Saxinger 2013b). For the employees and their families, however, oil and gas still symbolise guaranteed prosperity and individual social mobility. This fact exists alongside the feeling that people have been neglected by the state in terms of sustaining privileges that have been until recently provided to a much larger extent than today for the northern as well as the southern and central Russian long-distance commute workers. Nevertheless, the still high income in this sector means that even the southern and central Russian workers have part-time roots in the North and feel that they 
owe their socio-economic mobility to the extraction of oil and gas - some of the most precious and symbolically laden natural resources.

\section{NOTES}

${ }^{1}$ The classification of the Russian North comprises two spatial categories: Far North and regions equivalent to the Russian Far North. This is based on legal, socio-economical, political, demographical and socio-cultural aspects (Slavin 1982; Blakkisrud \& Hønneland 2006; Stammler-Gossmann 2007) that refer to the territories of northern latitude with harsh climate and environment, production costs and maintenance of the northern towns above the Russian average (Nuykina 2011). Henceforth the term North will be used in this article and comprises both zones.

${ }^{2}$ Interview with expert Gennadiy Bondarenko, Professor of Philosophy, State Technical Petroleum University Ufa (UGNTU), Interview in Ufa, conducted by the author, 2009.

${ }^{3}$ Quoted interview partners are anonymized. If not indicated otherwise, they are either intra-regional or inter-regional long-distance commuters. While the first are dwellers of the North, the second are living in central Russian regions. Interviews are taken in northern and central Russia by the author between 2007 and 2010.

${ }^{4}$ A street in Novy Urengoy is named after the first people who moved there: "ulitsa pervoprokhodtsev". ${ }^{5}$ Interview with expert Vladimir Nuykin, vice mayor of Novy Urengoy, interview conducted by the author and Elena Aleshkevich (Project Lives on the Move), 2010.

${ }^{6}$ On the current laws surrounding child support in Russia, see ILO (2013) and Zanprim.regiontrud.ru (2013).

\section{ACKNOWLEDGEMENTS}

This study is funded by the Austrian Science Foundation (FWF) [P 22066-G17] in the framework of the research project "Lives on the Move" (project leader Prof. Heinz Fassmann, duration 2010-2015) at the Department for Geography and Regional Research, University of Vienna, and at the Institute for Urban and Regional Research (ISR) at the Austrian Academy of Sciences: raumforschung.univie.ac.at/forschungsprojekte/lives-on-the-move. Funding is also provided by University of Vienna, Austrian Research Association (OEFG) and the Austrian Academy of Sciences (OEAW). Furthermore, this research is related to the ESF funded project BOEAS-MOVE INNOCOM at the Arctic Center in Rovaniemi, Finland. Special thanks to the anonymous reviewers and to Prof. Peter Schweitzer, Prof. Heinz Fassmann, Prof. Florian Stammler, Elisabeth Oefner and Dr. Elena Nuykina.

\section{REFERENCES}

Aleshkevich ES 2010. Implementation of policy decisions to develop the Far North: History of the longdistance commute work. In Stammler F \& Eilmsteiner-Saxinger G (eds). Biography, shift-labour and socialisation in a Northern Industrial City - The Far North: Particularities of labour and human socialisation, 109-115. Arctic Centre, University of Lapland, Finland. Department of Geography and Regional Research, University of Vienna, Austria. <https:// raumforschung.univie.ac.at/fileadmin/user_upload/ inst_geograph/BOOK_Biography-ShiftLabour-Socialisation-Russian_North.pdf> 15.04.2014.

Andreyev OP, Arabskiy AK, Kramar VS \& Silin AN 2009. Sistema menedzhmenta vakhtovogo metoda raboty predpriyatiya $v$ usloviyakh Kraynego Severa. Nedra, Moskva (in Russian).

Appadurai A 1988. The social life of things: Commodities in cultural perspective. University Press, Cambridge.

Blakkisrud H \& Hønneland G (eds) 2006. Tackling space. Federal politics and the Russian North. University Press of America, Lanham.

Bogudinova VN 1981. TEO ispol'zovaniya vakhtovykh metodov organisatsii truda na severe. Gazovaya promyshlennost' 8: 7, 19-19. (in Russian).

Bolotova A \& Stammler F 2010. How the North became home. Attachment to place among industrial migrants in Murmansk region. In Lee $\mathrm{H}$ \& Southcott C (eds). Migration in the Circumpolar North: Issues and contexts, 193-220. Canadian Circumpolar Institute Press, Edmonton.

Burawoy M 1998. The extended case method. Sociological Theory 16: 1, 4-33. http://dx.doi. org/10.1111/0735-2751.00040.

Directorate-General for Energy and Market Observatory for Energy 2011. Energy keyfigures. <http:// ec.europa.eu/energy/observatory/countries/doc/ key_figures.pdf> 15.04.2014.

Cresswell T 2004. Place: A short introduction. Blackwell, Malden.

Dudeck S 2010. Indigenous oil workers between the oil Ttwn of Kogalym and reindeer herder's camps in the surrounding area. In Stammler F \& Eilmsteiner-Saxinger G (eds). Biography, shift-labour and socialisation in a Northern Industrial City The Far North: Particularities of labour and human socialisation, 141-144. Arctic Centre, University of Lapland, Finland. Department of Geography and Regional Research, University of Vienna, Austria. <https://raumforschung.univie.ac.at/fileadmin/user_upload/inst_geograph/BOOK_Biography-ShiftLabour-Socialisation-Russian_North.pdf> 15.04.2014.

Eilmsteiner-Saxinger G \& Aleshkevich ES 2008. State and shift labor in Western Siberia. Conference paper: ICASS VI, Nuuk, Greenland. 26.08.2008.

Eilmsteiner-Saxinger G 2011. "We feed the nation": Benefits and challenges of simultaneous use of 
resident and long-distance commuting labour in Russia's northern hydrocarbon industry. Journal of Contemporary Issues in Business \& Government 17: 1, 53-67.

Eilmsteiner-Saxinger G 2013a. Bodenschätze und Menschenschätze - Zur sozialen und materialen Dimension der fossilen Rohstoffe in Nordwest-Sibirien im Kontext des Fernpendelns. In Donecker S, Eberhard I \& Hirnsperger M (eds). Wege zum Norden. Wiener Forschungen zu Arktis und Subarktis, 23-43. LIT, Vienna (in German).

Eilmsteiner-Saxinger G 2013b. Mobiles Leben der FernpendlerInnen in der Erdgas- und Erdölindustrie im Norden Russlands. Unpublished dissertation. University of Vienna, Vienna (in German).

EU Commission 2011. EU-Russia energy relations. <http://ec.europa.eu/energy/international/russia/russia_en.htm> 15.04.2014.

Euractiv 2010. Geopolitische Aspekte der EU-Energieversorgung. <http://www.euractiv.com/de/energie/geopolitische-aspekte-eu-energieversorgung/ article-142798> 15.04.2014. (in German).

Eurostat 2011. Energy, transport and environment indicators. European Commission, Luxembourg.

Ferguson J 2005. Seeing like an oil company: Space, security, and global capital in neoliberal Africa. American Anthropologist 107: 3, 377-382. http:// dx.doi.org/10.1525/aa.2005.107.3.377.

Ferguson J 2006. Global shadows: Africa in the neoliberal world order. Duke University Press, Durham, NC.

Fillipov DN 1982. Vsesoyusnyye udarnyye komsomol'skiye. Newspaper article in Ekonomicheskaya gazeta, 02.05.1982. (in Russian).

Gerasimchuk I 2012. Fossil fuels - At what cost? Government support for upstream oil and gas activities in Russia. WWF-Russia \& IISD, Moscow - Geneva. <http://www.iisd.org/gsi/sites/default/files/ffs awc_russia_eng.pdf> 15.04.2014. (in Russian).

Gustafson T 2012. Wheel of fortune: The battle for oil and power in Russia. Belknap of Harvard UP, Cambridge, London.

Heleniak T 2008. Changing settlement patterns across the Russian North at the turn of the millennium. In Rautio V \& Tykkyläinen M (eds). Russia's northern regions on the edge: Communities, industries, and populations from Murmansk to Magadan, 25-52. Aleksanteri Institute, Helsinki.

Heleniak TE 2009. Growth poles and ghost towns in the Russian Far North. In Wilson Rowe E (ed). Russia and the North, 129-163. University of Ottawa Press, Ottawa.

Hill F \& Gaddy C 2003. The Siberian curse: How communist planners left Russia out in the cold. Brookings Institution Press, Washington DC.

ILO 2013. NATLEX Russia. <https://www.ilo.org/ dyn/natlex/natlex_browse.details?p_lang=en\&p_ country $=R U S \& p_{-}$classification $=16 \& p_{-}$ origin $=$ COUNTRY\&p_sortby $=S O R T B Y \_C O U N-$ $T R Y>07.07 .2014$.

Ingold T 2011. Being alive: Essays on movement, knowledge and description. Routledge, London.
Kozlinskaya NM 2009. Osobennosti regulirovaniya truda lits, rabotaushchikh $v$ rayonakh Kraynego Severa i priravnennikh k nim mestnostyakh. Unpublished dissertation. Rossiyskaya akademiya pravosudiya, Moskva. <http://www.dissercat. com/content/osobennosti-regulirovaniya-trudalits-rabotayushchikh-v-raionakh-krainego-severa-ipriravnen> 15.04.2014. (in Russian).

Latour B 1993. We have never been modern. Harvester Wheatsheaf, New York.

Law J 1992. Notes on the theory of the actor-network: Ordering, strategy, and heterogeneity. Systems Practice and Action Research 5: 4, 379-393. http://dx.doi.org/10.1007/BF01059830.

Ljapin A 1952. Die Arbeit im Sozialismus. Tribüne, Berlin (in German).

Löw M 2001. Raumsoziologie. Suhrkamp, Frankfurt am Main (in German).

Löw M 2008. The constitution of space: The structuration of spaces through the simultaneity of effect and perception. European Journal of Social Theory 11: 1, 2549. http://dx.doi.org/10.1177/1368431007085286.

Martynov VG \& Moskalenko AA 2008. Kadrovaya politika kak instrument $v$ sisteme sotsial'noy otvetstvennosti biznesa. MAKS Press, Moskva (in Russian).

Massey DB 2005. For space. Sage, London.

Moe A \& Kryukov V 2010. Oil exploration in Russia: Prospects for reforming a crucial sector. Eurasian Geography and Economics 51: 3, 312-329. http:// dx.doi.org/10.2747/1539-7216.51.3.312.

Moe A \& Wilson Rowe E 2009. Northern offshore oil and gas resources. In Wilson Rowe E (ed). Russia and the North, 107-128. University of Ottawa Press, Ottawa.

Nash JC 1979. We eat the mines and the miners eat us: Dependence and exploitation in Bolivian tin mines. Columbia University Press, New York.

Nuykina E 2011. Resettlement from the Russian North: An analysis of state-induced relocation policy. Arctic Center Report 99. University of Lapland, Rovaniemi. <https://Www.doria.fi/bitstream/handle/10024/72513/AKreport55_electronic 110808.pdf? sequence $=1>03.11 .201 \overline{4}$.

Pashin ST 2004. My znali - Yamburg budet: 20 let 000 'Yamburggazdobycha'. In Belov A, Boris K \& Bashuk V (eds). Gazovyye okeany Yamburga, 6266. OOO Kniga-Penta, Moskva (in Russian).

Rouillard R 2013. Nomads in a petro-empire: Nenets reindeer herders and Russian oil workers in an era of flexible capitalism. Unpublished dissertation. McGill University, Montreal.

Regnum I 2011. Bashkiriya namerena privlech' v respublikanskiy byudzhet nalogi 'vakhtovikov'. $<w w w . r e g n u m . r u / n e w s / 1380267 . h t m />$ 15.04.2014. (in Russian).

Rosstat 2014. Srednemesyachnaya nominal'naya nachislenennaya zarabotnaya plata rabotnikov $v$ celom po ekonomike po sub'ektam Rossiyskoy Federacii v 2013-2014 gody. <http://www.gks.ru/ free_doc/new_site/population/trud/sr-zarplata/ t1.doc $>15.04 .2014$. (in Russian). 
Sapozhnikov PS \& Chudnovskiy AD 1988. Vakhtovyy metod osvoyeniya prirodnykh resursov Severa. Nedra, Moskva (in Russian).

Saxinger G, Öfner E, Shakirova E, Yakovlev M, Ivanova M \& Gareev E 2014. Ich bin bereit - Die nächste Generation mobiler Fachkräfte in der russischen Erdgas- und Erdölindustrie. Austrian Studies in Social Anthropology 2, 1-24. (in German)

Slavin SV 1982. Osvoyeniye Severa Sovetskogo Soyuza. Nauka, Moskva (in Russian).

Stammler F 2011. Oil without conflict? The anthropology of industrialisation in Northern Russia. In Behrends A, Reyna SP \& Schlee G (eds). Crude domination: An anthropology of oil, 243-269. Berghahn Books, Oxford.

Stammler F \& Eilmsteiner-Saxinger G 2010. Introduction: The Northern Industrial City as a place of life and of research. In Stammler F \& Eilmsteiner-Saxinger G (eds). Biography, shift-labour and socialisation in a Northern Industrial City - The Far North: Particularities of labour and human socialisation, $9 \neg-16$. Arctic Centre, University of Lapland, Finland. Department of Geography and Regional Research, University of Vienna, Austria. <https://raumforschung.univie.ac.at/fileadmin/ user_upload/inst_geograph/BOOK_BiographyShiftLabour-Socialisation-Russian_North.pdf> 14.04.2014.

Stammler-Gossmann A 2007. Reshaping the North of Russia: Towards a conception of space. Arctic and Antarctic Journal of Circumpolar Sociocultural Issues 1: 1, 53-97.

Stammler F \& Wilson E 2006. Dialogue for development: An exploration of relations between oil and gas companies, communities, and the state. Sibirica 5: 2, 1-42.

Stark M 2003. Frauen im Gulag. Alltag und Überleben: 1936 bis 1956. Hanser, München and Wien (in German).
Stern JP 2005. The future of Russian gas and Gazprom. Oxford Institute of Energy Studies, Oxford.

Stettner R 1996. Archipel GULag'. Stalins Zwangslager - Terrorinstrument und Wirtschaftsgigant: Entstehung, Organisation und Funktion des sowjetischen Lagersystems 1928-1956. Schöningh, Paderborn and Wien (in German).

Tumayev V 2009. The Gazprom song. <http://www. offshore.no/sak/34274_synger_for_gazprom> 15.04.2014.

UfaFinans.ru 2013a. Avtokredity v Ufe, avto kredit v Ufe. <http://ufafinans.ru/index.php/2010-02-2605-23-15? catid $=3>15.04 .2014$. (in Russian).

UfaFinans.ru 2013b. Ipoteka v Ufe, banky Ufy ipoteka. <http://ufafinans.ru/index.php/2010-02-2605-23-15? catid=6>15.04.2014. (in Russian).

UfaFinans.ru 2013c. Potrebitel'skiye kredit v Ufe. <http://ufafinans.ru/index.php/2010-02-26-0523-15? catid=5>15.04.2014. (in Russian).

Weichhart P 2009. Multilokalität - Konzepte, Theoriebezüge und Forschungsfragen. Informationen zur Raumentwicklung 1:2,1-14. (in German).

Wolf ER 1982. Europe and the people without history. University of California Press, Berkeley, CA.

Zanprim.regiontrud.ru 2013. Informatsiya ob indeksatsii gosudarstvennykh posobiy grazhdanam, imeyushchim detey s 1 yanvarya 2013 g. <http:// zanprim.regiontrud.ru/App_Shared/WebParts/ Dat a Viewers/PopupDocument. aspx?docid $=4435$ c439-a45d-4da7-9a03$1 d d b 458509 b 9>15.04 .2014$. (in Russian).

Zirm J 2007. Leben und arbeiten in 'Gazpromland'. Newspaper article in Die Presse, 01.12.2007. $<$ thtp://diepresse.com/home/wirtschaft/economist/346813/Leben-und-arbeiten-in-Gazpromland> 15.04.2014. (in German). 